\title{
Aspectos clínicos e patológicos da circovirose suína no Rio Grande do Sul*
}

\author{
ANDRÉ MENDES RIBEIRO CORRÊA
}

\author{
David Driemeier (Orientador - UFRGS)
}

Banca: Ana Lúcia Schild (UFPel), Aldo Gava (UDESC/CAV), Cláudio Severo Lombardo de Barros (UFSM).

Este estudo incluiu 523 suínos, entre três e quatro meses de idade, com sinais clínicos sugestivos de circovirose. A maioria (471) desses animais foi recebida viva no Setor de Patologia Veterinária - SPV/UFRGS, onde foram avaliados clinicamente, eutanasiados e necropsiados. Os principais sinais observados foram caquexia, crostas eritematosas circulares na pele, alterações articulares, palidez ou icterícia de mucosas, diarréia, sinais respiratórios e sinais nervosos. Os principais achados macroscópicos foram linfadenomegalia, pulmões não colapsados, consolidações pulmonares, hiperqueratose do quadrilátero esofágico, esplenomegalia, rins pálidos ou amarelados com pontos brancos, ascite, hidropericárdio e hidrotórax. Fragmentos de pele, linfonodo inguinal, linfonodo mesentérico, tonsila, baço, íleo, cólon, fígado, rim, pulmão, coração e cérebro foram coletados e processados convencionalmente para histologia. As principais alterações microscópicas incluíram infiltrado linfoistiocitário e depleção centrofolicular em órgãos linfóides, infiltrado linfoistiocitário nos intestinos, pneumonia intersticial, hepatite portal mononuclear, nefrite intersticial e hiperplasia centrofolicular, edema e dilatação de vasos linfáticos dos intestinos e linfonodos. Amostras de cólon e íleo de 111 suínos que apresentavam conteúdo de consistência fluida foram coletadas e processadas para bacteriologia. Em 27 desses animais foram detectados agentes bacterianos patogênicos. E. coli foi o mais prevalente, mas Salmonella sp. e Brachyspira sp. também foram detectadas. Cortes de linfonodos mesentéricos, pulmões, rins e intestinos de 56 animais foram submetidos à imunoistoquímica com anticorpo policlonal anti-PCV2. Destes, amostras de 50 foram positivas. Os achados clínicos e macroscópicos desses animais foram compatíveis com circovirose, mas a associação de lesões histológicas características da doença com a presença do PCV2, demonstrada imunoistoquímicamente, foi diagnóstica.

Descritores: circovírus, circovirose, PCV2, suíno, imunoistoquímica, patologia, clínica.

Apresentada: 24 fevereiro 2006

"Dissertação de Mestrado n. 429 (Especialidade: Patologia Animal). 77f. Programa de Pós-graduação em Ciências Veterinárias [www.ufrgs.br/ ppgcv], Faculdade de Veterinária, Universidade Federal do Rio Grande do Sul (UFRGS), Porto Alegre, RS/Brasil. CORRESPONDÊNCIA: AM.R. Corrêa [amrcorrea@hotmail.com]. 


\title{
Clinical and pathological aspects of swine circovirosis in Southern Brazil ${ }^{* *}$
}

\author{
ANDRÉ MENDES RIBEIRO CORRÊA
}

\author{
David Driemeier (Adviser - UFRGS)
}

Committee: Ana Lúcia Schild (UFPel), Aldo Gava (UDESC/CAV), Cláudio Severo Lombardo de Barros (UFSM).

This report includes 523 pigs 3-4-month-old that showed clinical signs suggestive of circovirosis. Most of them (471) arrived alive in the Department of Veterinary Pathology - UFRGS, where they were clinically evaluated, euthanized and necropsied. The main signs were emaciation, rounded eritematous skin lesions, articular lesions, pale or icteric mucosae membranes, diarrhea, and signs of respiratory and nervous disorders. The major gross lesions included enlarged lymph nodes and spleen, non collapsed lungs, lung consolidations, esophagic hyperkeratosis, pale or yellow kidneys with white spots, ascites, hydropericardium, and hydrothorax. Fragments of skin, lymph nodes (mesenteric, inguinal), tonsils, spleen, ileum, colon, liver, kidneys, lungs, heart, and brain were sampled and conventionally processed. Histological findings were mainly lymphohistiocytic infiltrates and centrofolicular depletion in lymphoid tissues, lymphohistiocytic infiltrates within intestines, interstitial pneumonia, mononuclear portal hepatitis, interstitial nephritis, and centrofolicular hyperplasia, oedema, and dilatation of lymphatic vessels from intestines and lymph nodes. A number of additional findings were also described. Samples of colon and ileum from 111 pigs, in which intestinal contents were liquid, were processed for bacteriology and in 27 of those pathogenic bacteria were detected. E. coli was the most prevalent, but Salmonella sp. and Brachyspira sp. were also present. Sections of mesenteric lymph nodes, lungs, kidneys, and intestines from 56 pigs were processed for immunohistochemical probing using polyclonal antibody against to PCV2. Positive reactions were seen in sections from 50 of those samples. The clinical and macroscopic findings of these animals were consistent with circovirosis, but the association of the characteristic microscopic lesions with the presence of PCV2, immunohistochemically demonstrated, was diagnostic for this disease.

Key words: circovirus, circoviruses, PCV2, swine, immunohistochemistry, pathology, clinic.

Presented: 24 February 2006

\footnotetext{
${ }^{* *}$ Master's Thesis \# 429 (Field: Veterinary Pathology). 77p. Graduate Program in Veterinary Sciences [www.ufrgs.br/ppgcv], Faculdade de Veterinária, Universidade Federal do Rio Grande do Sul (UFRGS), Porto Alegre, RS/Brazil. CORRESPONDÊNCIA: A.M.R. Corrêa [amrcorrea@hotmail.com].
} 